\title{
Auto Mechanic Students' Perceptions and Readiness toward Mobile Learning in Thailand
}

\author{
https://doi.org/10.3991/ijim.v12i5.8906 \\ Ekkalak Issaramanoros, Jintavee Khlaisang( $\left.{ }^{\bowtie}\right)$, Pakawan Pugsee \\ Chulalongkorn University, Bangkok, Thailand \\ jintavee.mechula.ac.th
}

\begin{abstract}
Access to quality education is now a huge challenge in Thailand with ever-increasing inequality between rural and urban populations. Existing teaching and learning facilities are no longer adequate. Mobile learning has been suggested as a sustainable and appropriate delivery mechanism to reduce this rural/urban education gap. Students are supplied with their own mobile device at no cost to learners or their families. Opportunities offered through mobile learning to auto mechanic education in Thailand were explored. Data from 384 auto mechanic students were collected and descriptive and multiple regression analyses were performed based on the unified theory of acceptance and use of technology 2 (UTAUT2) model. Results showed that performance expectancy, effort expectancy, social influence, facilitating conditions, hedonic motivation and personal innovativeness were positively related to behavioral intention to use mobile learning. Furthermore, effort expectancy, hedonic motivation and personal innovativeness were the most significant predictors of behavioral intention to use mobile learning. Auto mechanic students in Thailand had positive perceptions toward mobile learning and the effect of students' effort expectancy provided a better explanation for the adoption of mobile learning in auto mechanic education.
\end{abstract}

Keywords-Mobile learning, Technology Readiness, Auto mechanic education

\section{Introduction}

The automotive industry in Thailand has for several decades been a priority sector both supported and encouraged by the government. In 2015, the Thai Government released the Super-Cluster strategic initiative which was designed to link Thailand's industry cluster assets and strengthen the clusters by adding mission-critical elements to help businesses become more efficient and competitive. The automotive and parts cluster was targeted as a suitable industry [1]. Thailand has an adequate supply of low-skilled labor but the country faces an acute shortage of highly-skilled automotive engineers and cannot meet the needs of industry [2]. Although sufficient vocational training courses are provided by training schools in the greater Bangkok area, there is limited access to vocational education in rural areas, and also for disadvantaged groups. This continues to be a major issue throughout the country [3]. The education 
system urgently requires the introduction of user-friendly training which can be delivered at a convenient time for students through appropriate modes of learning. This may take the form of mobile training, distance learning, strengthening training by master craftsmen and such other innovative modes of training delivery [4]. Using the readily available technology of e-communication, mobile learning can become more focused with increased and enhanced flexibility of access and learning opportunity [5].

Research has shown that technologies such as e-learning, and more recently mobile learning, may have the potential to facilitate teaching and learning modules that can positively address the problem of poor access to education suffered by people in rural areas [6]. Mobile learning can be viewed as an extension of e-learning but differs in the sense that it uses mobile devices rather than computers as the learning medium [7]. Mobile learning is considered by many as a modern and most appropriate delivery mechanism for educational information and a sustainable method of overcoming rural poverty [8].

To clearly highlight the knowledge gap which this study seeks to fill, the next section reviews some relevant studies that have been carried out in Thailand as well as in other parts of the world. Whilst older people have expectations and past experiences based on a history of learning with computers, younger people's lives have been shaped by mobile devices as a universal social phenomenon. This has evolved into opportunities to create, share, discuss, transform, store and distribute ideas, images, information, identities and opinions, and thus perhaps challenge the traditional concept of learning and education shaped by schools and teachers. These ideas, experiences and definitions of learning with mobile devices were therefore imported and given the particular background and context of the national educational situation in Thailand. Thus, this study will investigate the perception and influence factors on intention to use mobile learning of auto mechanic students.

The third section explains the theoretical underpinnings and data collection of the research and examines how the UTAUT2 model can be adapted to the Thai environment. The fourth section describes the results in detail, followed by a critical analysis and discussion of the findings. Conclusions are drawn, study limitations are noted and possibilities for further research are suggested in the final section.

\section{Literature review}

A number of studies have been conducted across the globe which reveal that mobile learning is potentially viable in addressing the various challenges of teaching and educational instruction. This section reviews some papers which utilize the unified theory of acceptance and use of the technology 2 (UTAUT2) model to explain factors that influence the acceptance and use of mobile learning in different and varied contexts. 


\subsection{Mobile Learning}

Mobile learning is an emerging technology which represents a novel way to address a number of educational problems, especially in places where resources are inadequate. The concept involves the use of mobile technology, either alone or in combination with other information sources, to facilitate and enable education for teaching and learning purposes anywhere and anytime [9]. The use of mobile technology goes a long way toward overcoming the challenges that are facing the education sector and especially in developing countries. Mobile technology has been used to support learning in both virtual and physical environments [10]. One of the advantages of mobile learning is that it is affordable by the majority, even those who are low-income earners [11] as many already own a mobile device [12]. Numerous academics have discussed mobile learning models. Results have shown that the technological environment and infrastructure, needs, pedagogy, choices and expectation of the country were important to develop the appropriate mobile learning system [1316]. Moreover, mobile learning is fast becoming recognized, accepted and considered as the next generation of distance learning and the best way to enhance learning and teaching outside the classroom [18-19]. Learner, teacher, content, technology and environment are the basic elements and core characteristics at the heart of mobile learning, with learners at the center of all these learning activities. Mobile learning should build on and develop learners' interests, experiences, expectations and needs [20]. Furthermore, regularity and standards such as education policy and market regulations also play a vital and important role [9]. However, many of these new extremely recent developments in mobile learning require changes in mindset and overall university strategy [21]. Mobile learning does not only require technology to succeed. The overall marketing approach must be adapted and tailored to a new way of thinking about and viewing the whole concept of education. This will involve a radical change to embrace a more enlightened techno-social ethic based on advanced technology development and engagement [22].

\section{$2.2 \quad$ UTAUT2}

This study is underpinned by a modified version of the UTAUT2 model as a powerful predicting framework [23]. The theory purports that seven constructs as performance expectancy, effort expectancy, social influence, facilitating conditions, hedonic motivation, price value and habit influence the behavioral intention and usage behavior of individuals toward acceptance and use of technology in organizational contexts. Additionally, gender, age and user experience are included as moderating variables. Data from mobile internet consumers were collected as basic input for the UTAUT2 model.

There have been many variant applications of the UTAUT2 model, based on the application context. Price value in the original model focused on the cost associated with the purchase of devices and services. Therefore, since this study deals with mobile learning and many learners already own their own mobile device [12], the price value or cost of the model was removed and not considered. In addition, habit is de- 
fined as the extent to which people tend to perform behaviors automatically because of learning that reflects and remembers the results of prior experiences. Therefore, this study focused on mobile learning as a new concept in auto mechanic education in Thailand. Personal innovativeness can be defined as a person's openness toward new technology systems, information or new experiences [24]. Therefore, this study renamed habit in the UTAUT2 model as personal innovativeness as shown in Figure 1.

A critical review of previous studies from a global perspective to the Thailand context revealed that most research was carried out at university level. However, past experience has shown that different affordances which include physical infrastructure such as electricity, internet connectivity, availability or shortage of computers, and other environmental or cultural factors affect the readiness of both acceptance and adoption of mobile learning $[23,25]$. In other words, the situation in universities cannot be generalized to other categories of higher education institutions because of the different affordances of the student learners. Furthermore, the study focused on auto mechanic education. A shortage of industry-ready skilled workers presents one of the biggest challenges for the automotive industry which is one of the key growth areas in Thailand [26].

The wide use of mobile devices which was indicated in previous studies conducted in Thailand both suggested and provided that impetus for this study which forms part of an ongoing research to explore the viability of mobile learning in Thailand auto mechanic education, using a variation of the UTAUT2 model as the underpinning theory. The study determined the extent of perceptions and readiness of students in auto mechanic education in Thailand toward mobile learning using the constructs from the UTAUT2 model and was guided by the two research questions listed below:

RQ1: What are the perceptions of students toward mobile learning?

RQ2: To what extent does performance expectancy, effort expectancy, social influence, facilitating conditions, hedonic motivation and personal innovativeness influence students' intentions to use mobile learning in auto mechanic education?

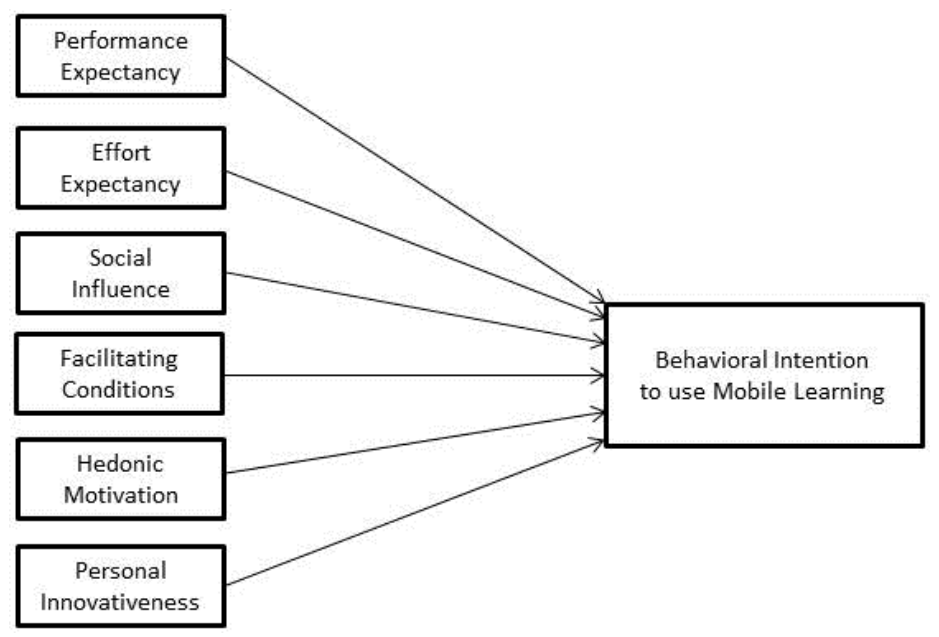

Fig. 1. Conceptual model 


\section{$3 \quad$ Methodology}

\subsection{Sampling and data collection}

The survey followed a data collection technique widely used in studies predicting attitudes toward information technology [27]. The study was performed from August to November 2017. Participants included 384 auto mechanic students in Thailand who were selected using multistage sampling. Firstly, vocational colleges in Thailand as two groups of 12 public vocational colleges and 7 private vocational colleges were randomly selected. Secondly, a stratified proportionate sampling technique was used to estimate the number of students to include from each of the selected vocational colleges. This technique yielded 266 and 118 students from the public and private vocational colleges, respectively.

Based on the estimated study sample, 475 copies of the research instrument were administered to respondents face-to-face during classes. Participants were selected as volunteers as they could refuse to fill in the survey. A formal letter was sent to the Director of each of the selected vocational schools to request permission to conduct the survey. A copy of the questionnaire was enclosed so that they were aware of the data to be collected. Once the vocational schools received the documentation, they assigned a teacher to assist in the process of obtaining the data. Also, before completing the questionnaire, all students received research information and a contact email in class. Since the researcher strictly followed this formal method of data collection, the result was an excellent return rate of $80.84 \%$ (384).

\subsection{Questionnaire}

A questionnaire was used as the data collection instrument. This comprised two sections as demographic information and perceptions of the auto mechanic students of mobile learning. All questionnaire items were adopted from existing studies (for details of sources, see Appendix A). The questionnaire topics and questions had all undergone consultations with experts in the auto mechanic education field to ensure clarity and suitability of the content and format. A five-point Likert scale was used to capture the responses (ranging from 1 Strongly disagree, 2 Disagree, 3 Neutral, 4 Agree, and 5 Strongly agree). All questions in the questionnaire were written in the Thai language as this was the mother tongue of the participants. Pertinent demographic questions were also included in the survey.

\subsection{Instruments}

Instruments were taken from similar studies that intended to identify intention toward the adoption of mobile technology [28]. To determine the reliability of the instrument, specifically with regard to internal consistency, Cronbach's alpha was measured for the constructs and results are presented in Table 1. All of the constructs demonstrated Cronbach's alpha values above 0.7 and were deemed to be internally consistent. 
Table 1. Reliability of scale used

\begin{tabular}{|l|c|c|}
\hline \multicolumn{1}{|c|}{ Construct } & Cronbach's Alpha & No. of Items \\
\hline Performance Expectancy & .868 & 3 \\
\hline Effort Expectancy & .792 & 3 \\
\hline Social Influence & .785 & 3 \\
\hline Facilitating Conditions & .850 & 3 \\
\hline Hedonic Motivation & .845 & 6 \\
\hline Personal Innovativeness & .850 & 3 \\
\hline Behavioral Intention & .842 & 3 \\
\hline
\end{tabular}

\subsection{Data analysis}

Data were analyzed using the Statistical Package for the Social Sciences (SPSS) version 22. First, the perceptions of students were determined and then a regression analysis was used to ascertain the extent to which all factors (the constructs of the independent variables as performance expectancy, effort expectancy, social influence, facilitating conditions, hedonic motivation and personal innovativeness) contributed to the readiness of participants toward mobile learning (behavioral intention).

\section{$4 \quad$ Results}

\subsection{Demographic information}

The sample consisted of 384 participants, most were males $(97.7 \%)$ with a small proportion of females (2.3\%). Most participants were aged between 16 and 25 years $(97.9 \%)$, followed by those aged between 26 and 35 years $(1.8 \%)$. In terms of year of study, most respondents $(59.1 \%)$ were in the first year followed by second year $(40.9 \%)$. The majority of respondents $(93.8 \%)$ owned only a smartphone, while $4.9 \%$ owned both a smartphone and a tablet and $1.3 \%$ did not own any smart devices. Furthermore, results showed that $52.9 \%$ of respondents used their mobile device for learning at their home, while $44 \%$ used mobile learning at their school and $3.1 \%$ used their mobile devices during travel (Table 2).

Table 2. Demographic $(n=384)$

\begin{tabular}{|l|l|c|c|}
\hline \multicolumn{2}{|c|}{ Construct } & Number & Percent \\
\hline \multirow{2}{*}{ Vocational college } & Public & 266 & $69.3 \%$ \\
\cline { 2 - 4 } & Private & 118 & $30.7 \%$ \\
\hline \multirow{2}{*}{ Gender } & Male & 375 & $97.7 \%$ \\
\cline { 2 - 4 } & Female & 9 & $2.3 \%$ \\
\hline \multirow{2}{*}{ Age } & $16-25$ & 377 & $97.9 \%$ \\
\cline { 2 - 4 } & $26-35$ & 7 & $1.8 \%$ \\
\hline Year of study & High vocational $-1^{\text {st }}$ & 227 & $59.1 \%$ \\
\hline
\end{tabular}




\begin{tabular}{|l|l|c|c|}
\hline & High vocational $-2^{\text {nd }}$ & 157 & $40.9 \%$ \\
\hline \multirow{5}{*}{ Smart device ownership } & Smartphone only & 360 & $93.8 \%$ \\
\cline { 2 - 4 } & Tablet only & 0 & $0 \%$ \\
\cline { 2 - 4 } & Smartphone and tablet & 19 & $4.9 \%$ \\
\cline { 2 - 4 } & No use & 5 & $1.3 \%$ \\
\hline \multirow{3}{*}{ Most used location } & Home & 203 & $52.9 \%$ \\
\cline { 2 - 4 } & School & 169 & $44 \%$ \\
\cline { 2 - 4 } & During travel & 12 & $3.1 \%$ \\
\hline
\end{tabular}

\subsection{Perception of students toward mobile learning}

Descriptive analysis was conducted to study the respondents' perceptions concerning the use of mobile learning. Results of the analysis are shown in Table 3.

In terms of mobile learning perceptions, respondents mostly agreed that they had intention to experiment with new information technologies. (mean=4.02). This finding indicated that contents in mobile learning were much more convenient to use (mean=3.97). However, some respondents were concerned about the ability of mobile devices to perform mobile learning (mean=3.94). In addition, some also agreed that mobile learning provided high levels of learning (mean=3.85). Furthermore, some respondents agreed that their colleges supported the use of mobile learning $($ mean $=3.85)$ and they were provided with the resources necessary to use mobile learning systems $($ mean $=3.85$ ). Due to this, some respondents considered that mobile learning was very interesting (mean=3.86) and others suggested that mobile phones were not boring for learning (mean=3.27).

Table 3. Student Perceptions on Mobile learning

\begin{tabular}{|l|l|c|c|}
\hline & \multicolumn{1}{|c|}{ Items } & Mean & SD \\
\hline 1 & I have intention to perform mobile learning & 3.81 & .935 \\
\hline 2 & I am going to positively utilize mobile learning & 3.92 & .874 \\
\hline 3 & $\begin{array}{l}\text { I have continuing concern about mobile devices of information to perform } \\
\text { mobile learning }\end{array}$ & 3.94 & .984 \\
\hline 4 & Mobile learning would improve my learning performance & 3.79 & .858 \\
\hline 5 & Mobile learning can improve efficiency of learning & 3.69 & .994 \\
\hline 6 & Mobile learning gives me high effects of learning & 3.85 & .978 \\
\hline 7 & It is easy to download and save learning contents with mobile devices & 3.88 & .995 \\
\hline 8 & It is easy to use menu of mobile devices and software & 3.76 & .878 \\
\hline 9 & It is easy to use mobile learning contents & 3.97 & .812 \\
\hline 10 & People who influence my behavior will think that I should use mobile learning & 3.67 & .981 \\
\hline 11 & $\begin{array}{l}\text { The lecturers and other staff at my college will be helpful in the use of mobile } \\
\text { learning }\end{array}$ & 3.67 & .916 \\
\hline 12 & In general, my college will support the use of mobile learning & 3.85 & 1.005 \\
\hline 13 & I have the resources necessary to use the system. & 3.67 & .943 \\
\hline 14 & I have the knowledge necessary to use the system & 3.66 & .880 \\
\hline
\end{tabular}




\begin{tabular}{|l|l|c|c|}
\hline 15 & A specific person (or group) is available for assistance with system difficulties & 3.66 & .915 \\
\hline 16 & When using mobile learning, I will forget the work I must do. & 3.74 & .975 \\
\hline 17 & Using mobile learning will give enjoyment to me for my learning. & 3.74 & .953 \\
\hline 18 & Using mobile learning will lead to my exploration. & 3.67 & .892 \\
\hline 19 & I would find mobile phone very interesting to use & 3.86 & .926 \\
\hline 20 & I would find mobile phone boring to use for learning & 3.27 & 1.105 \\
\hline 21 & I would find mobile phone exciting to use for learning & 3.85 & .862 \\
\hline 22 & I like to experiment with new information technologies. & 4.02 & .928 \\
\hline 23 & $\begin{array}{l}\text { When I hear about a new information technology I look forward to examining } \\
\text { it. }\end{array}$ & $\begin{array}{l}\text { Among my colleagues, I am usually the first to try out a new innovation in } \\
\text { technology. }\end{array}$ & 3.91 \\
\hline
\end{tabular}

\subsection{Readiness and factors that influence intentions to use mobile learning}

The process of ascertaining the extent to which the independent variables predicted the intentions of students to use mobile learning, the relationships between each independent variable and intentions to use mobile learning were ascertained and results are presented in Table 4.

Finding indicated that moderate positive relationships existed between performance expectancy and students' intentions to use mobile learning $(r=0.649, n=384$, $\mathrm{p}<0.001)$, between social influence and behavioral intention $(\mathrm{r}=0.630, \mathrm{n}=384, \mathrm{p}<$ $0.001)$, between facilitating condition and behavioral intention $(\mathrm{r}=0.577, \mathrm{n}=384, \mathrm{p}$ $<0.001)$, between hedonic motivation and behavioral intention $(\mathrm{r}=0.666, \mathrm{n}=384, \mathrm{p}$ $<0.001)$, and between personal innovativeness and behavioral intention $(r=0.661, n$ $=384, \mathrm{p}<0.001)$. Interestingly, results indicated that a strong positive relationship existed between effort expectancy and intentions of students toward mobile learning $(\mathrm{r}=0.702, \mathrm{n}=384, \mathrm{p}<0.001)$.

Table 4. Correlations

\begin{tabular}{|c|l|c|c|c|c|c|c|c|}
\hline \multicolumn{2}{|c|}{} & PE & EE & SI & FC & HM & PI & BI \\
\hline \multirow{4}{*}{ PE } & Pearson Correlation & 1 & & & & & & \\
\hline & Sig. (2-tailed) & & & & & & & \\
\hline & $\mathrm{N}$ & 384 & & & & & & \\
\hline \multirow{5}{*}{ EE } & Pearson Correlation & $.759^{* *}$ & 1 & & & & & \\
\cline { 2 - 10 } & Sig. (2-tailed) & .000 & & & & & & \\
\hline & $\mathrm{N}$ & 384 & 384 & & & & & \\
\hline \multirow{3}{*}{ SI } & Pearson Correlation & $.589^{* *}$ & $.633^{* *}$ & 1 & & & & \\
\cline { 2 - 10 } & Sig. (2-tailed) & .000 & .000 & & & & & \\
\cline { 2 - 10 } & $\mathrm{N}$ & 384 & 384 & 384 & & & & \\
\hline \multirow{3}{*}{ FC } & Pearson Correlation & $.560^{* *}$ & $.559^{* *}$ & $.622^{* *}$ & 1 & & & \\
\cline { 2 - 10 } & Sig. (2-tailed) & .000 & .000 & .000 & & & & \\
\hline & $\mathrm{N}$ & 384 & 384 & 384 & 384 & & & \\
\hline
\end{tabular}




\begin{tabular}{|l|l|c|c|c|c|c|c|c|}
\hline \multirow{4}{*}{ HM } & Pearson Correlation & $.666^{* *}$ & $.688^{* *}$ & $.659^{* *}$ & $.670^{* *}$ & 1 & & \\
\cline { 2 - 10 } & Sig. (2-tailed) & .000 & .000 & .000 & .000 & & & \\
\cline { 2 - 10 } & $\mathrm{N}$ & 384 & 384 & 384 & 384 & 384 & & \\
\hline \multirow{3}{*}{ PI } & Pearson Correlation & $.666^{* *}$ & $.682^{* *}$ & $.633^{* *}$ & $.529^{* * *}$ & $.607^{* *}$ & 1 & \\
\cline { 2 - 10 } & Sig. (2-tailed) & .000 & .000 & .000 & .000 & .000 & & \\
\cline { 2 - 10 } & $\mathrm{N}$ & 384 & 384 & 384 & 384 & 384 & 384 & \\
\hline \multirow{3}{*}{ BI } & Pearson Correlation & $.649^{* *}$ & $.702^{* *}$ & $.630^{* *}$ & $.577^{* *}$ & $.666^{* *}$ & $.661^{* *}$ & 1 \\
\cline { 2 - 10 } & Sig. (2-tailed) & .000 & .000 & .000 & .000 & .000 & .000 & \\
\cline { 2 - 10 } & $\mathrm{N}$ & 384 & 384 & 384 & 384 & 384 & 384 & 384 \\
\hline
\end{tabular}

Results shown in Table 4 suggested that all six independent variables had positive relationships with intention. This implies that the level of student readiness in Thai vocational colleges toward mobile learning increases moderately the more they perceive that mobile learning is useful to them. Similarly, their level of readiness toward accepting mobile learning increases moderately the more they perceive that their friends and significant others support their use of mobile learning. The same situation unfolds the more students perceive the level of availability of facilitating conditions. In the same way, emotional motivations of mobile learning and individual attitudes concerning accepting the innovation have moderate positive relationships. On the other hand, level of readiness of students toward accepting mobile learning increases very strongly the more they perceive the ease of use. By implication, more favorable ease of use promotes stronger readiness of students.

This implies that the level of readiness of students increases more with an increase in effort expectancy, as compared to corresponding increases in performance expectancy, social influence, facilitating conditions, hedonic motivation and personal innovativeness.

Table 5 shows results of the regression analysis. This indicates the extent to which the six independent variables (performance expectancy, effort expectancy, social influence, facilitating conditions, hedonic motivation and personal innovativeness) influence the readiness of students toward accepting mobile learning.

Table 5. Regression Analysis

\begin{tabular}{|c|c|c|c|c|c|c|c|c|}
\hline & \multirow{2}{*}{ Model } & \multicolumn{2}{|c|}{$\begin{array}{c}\text { Unstandardized Coeffi- } \\
\text { cients }\end{array}$} & \multirow{2}{*}{$\begin{array}{c}\begin{array}{c}\text { Standardized } \\
\text { Coefficients }\end{array} \\
\text { Beta }\end{array}$} & \multirow[t]{2}{*}{ t } & \multirow{2}{*}{ Sig. } & \multicolumn{2}{|c|}{$\begin{array}{l}\text { Collinearity } \\
\text { Statistics }\end{array}$} \\
\hline & & $B$ & Std. Error & & & & Tolerance & $V I F$ \\
\hline \multirow{2}{*}{1} & (Constant) & 1.071 & 149 & & 7.185 & .000 & & \\
\hline & $\mathrm{EE}$ & .729 & .038 & .702 & 19.240 & .000 & 1.000 & 1.000 \\
\hline \multirow{3}{*}{2} & (Constant) & .406 & .166 & & 2.441 & .015 & & \\
\hline & EE & .481 & .049 & .463 & 9.825 & .000 & .526 & 1.900 \\
\hline & $\mathrm{HM}$ & .441 & .060 & .347 & 7.374 & .000 & .526 & 1.900 \\
\hline \multirow{3}{*}{3} & (Constant) & .218 & .163 & & 1.340 & .181 & & \\
\hline & EE & .339 & .053 & .326 & 6.417 & .000 & .415 & 2.409 \\
\hline & $\mathrm{HM}$ & .351 & .059 & .277 & 5.921 & .000 & .491 & 2.036 \\
\hline
\end{tabular}




\begin{tabular}{|l|l|l|l|l|l|l|l|l|}
\hline & PI & .269 & .046 & .271 & 5.836 & .000 & .499 & 2.005 \\
\hline \multirow{4}{*}{4} & (Constant) & .209 & .161 & & 1.299 & .195 & & \\
\cline { 2 - 9 } & EE & .308 & .053 & .297 & 5.805 & .000 & .401 & 2.492 \\
\cline { 2 - 9 } & HM & .285 & .062 & .224 & 4.571 & .000 & .435 & 2.300 \\
\cline { 2 - 9 } & PI & .227 & .048 & .228 & 4.767 & .000 & .458 & 2.181 \\
\cline { 2 - 9 } & SI & .145 & .046 & .149 & 3.143 & .002 & .464 & 2.156 \\
\hline \multirow{4}{*}{5} & .179 & .161 & & 1.116 & .265 & & \\
\cline { 2 - 9 } & Constant) & .302 & .053 & .291 & 5.710 & .000 & .400 & 2.500 \\
\cline { 2 - 9 } & EE & .235 & .067 & .185 & 3.536 & .000 & .378 & 2.642 \\
\cline { 2 - 9 } & PI & .220 & .048 & .221 & 4.639 & .000 & .456 & 2.191 \\
\cline { 2 - 9 } & .120 & .047 & .124 & 2.522 & .012 & .433 & 2.307 \\
\cline { 2 - 8 } & SI & .097 & .096 & 2.073 & .039 & .488 & 2.050 \\
\hline
\end{tabular}

Facilitating Conditions. It can be inferred from Table 5 that facilitating conditions significantly predicted students' readiness toward mobile learning $(\beta=.096, \mathrm{p}<.05)$. This implies that for every unit increase in the level of availability of facilitating conditions, students' readiness toward accepting mobile learning also increases by $9.6 \%$ of the value of the standard deviation of behavioral intention. In other words, an increase in facilitating conditions causes a corresponding effect on behavioral intention.

Social Influence. Social influence significantly predicted students' readiness toward mobile learning $(\beta=.124, p<.05)$. This implies that for every unit increase in an individual's belief that important others believe they should use mobile learning; students' readiness toward accepting mobile learning also increases by $12.4 \%$ of the value of the standard deviation of behavioral intention. In other words, an increase in social influence causes a corresponding effect on behavioral intention.

Personal Innovativeness. Personal innovativeness significantly predicted students' readiness toward mobile learning $(\beta=.221, \mathrm{p}<.001)$. This implies that for every unit increase in an individual's attitude concerning accepting the innovation, students' readiness toward accepting mobile learning also increases by $22.1 \%$ of the value of the standard deviation of behavioral intention. In other words, an increase in personal innovativeness causes a corresponding effect on behavioral intention.

Hedonic motivation. Hedonic motivation significantly predicted students' intention to use mobile learning $(\beta=.185, \mathrm{p}<.001)$. This implies that for every unit increase in the emotional motivations of mobile learning, students' readiness toward accepting mobile learning also increases by $18.5 \%$ of the value of the standard deviation of behavioral intention. In other words, an increase in hedonic motivation causes a corresponding effect on behavioral intention.

Effort Expectancy. Effort expectancy significantly predicted students' intention to use mobile learning $(\beta=.291, \mathrm{p}<.001)$. This implies that for every unit increase in the ease of use of mobile learning, students' readiness toward accepting mobile learning also increases by $29.1 \%$ of the value of the standard deviation of behavioral intention. In other words, an increase in effort expectancy causes a corresponding effect on behavioral intention. 


\section{Discussion}

Results obtained aligned with the study objectives. A demographic analysis was presented in the first section and showed that $97.7 \%$ of auto mechanic students were male and most used only a smartphone (93.8\%). The second section of the results answered the first research question and determined that the perceptions of students revealed significant agreement of all items estimated as the seven constructs. The third part of the results answered the second research question and ascertained the readiness of students toward mobile learning and factors that influenced students' intentions to use mobile learning. These results also corroborated the first section and revealed that all six independent variables were positively correlated with behavioral intention, providing an indication of students' readiness toward accepting mobile learning. Performance expectancy, social influence, facilitating conditions, hedonic motivation and personal innovativeness all had a moderate association with behavioral intention, whereas effort expectancy had a strong correlation with behavioral intention. This finding concurred with a survey of mobile learning acceptance for university students in Thailand, as pointed out in a previous study, which demonstrated that students had a good perception of mobile learning and perceived ease of use had a high level of acceptance [29].

Moreover, correlation analysis was used to confirm effort expectancy, personal innovativeness, hedonic motivation, social influence and facilitating conditions as all predictors of students' intentions toward accepting mobile learning, with effort expectancy the greatest predictor of intention. This finding agreed with results of a previous study confirming that individuals' intentions to use mobile learning will increase as new technology becomes compatible with their living requirements [30]. The findings indicated that performance expectancy did not significantly predict students' intentions to accept mobile learning. One possible explanation for this result is that mobile learning has not been utilized in these colleges; thus, students do not have experience of the benefits to be gained from mobile technology.

Additionally, the five constructs as effort expectancy, personal innovativeness, hedonic motivation, social influence and facilitating conditions explained $60.7 \%$ of the variance in behavioral intention to use mobile learning. However, variance in the students' intentions explained by the model was lower than the original UTAUT2 $(74 \%)$. As pointed out earlier, this may be because mobile learning is still a new concept in vocational colleges in Thailand.

\section{Conclusions}

This study was designed to determine the perceptions of students toward mobile learning using the constructs based on the UTAUT2 model. Although mobile learning has not yet been widely implemented in vocational colleges in Thailand, results indicated that students were optimistic regarding its value and expressed their readiness to adopt this new and interesting concept. Effort expectancy is conducive to mobile learning. For this reason, students are keen to adopt mobile learning introduction in 
vocational colleges. Results indicated that although mobile learning is not a panacea for the educational challenges facing Thailand, it is a promising way of increasing accessibility to learning. Additionally, the use of UTAUT2 enhanced our understanding of the factors that affect the intention to use mobile learning. Although only at the preliminary stage, this study offers some insight into the challenges facing students in vocational colleges in Thailand. However, results explained only $60.7 \%$ of the variance in behavioral intention. There may be other factors that account for the missing variance. Hence, a broader investigation into the intention to use mobile learning in vocational colleges in Thailand should be undertaken, with a view to ascertaining other additional factors that could account for the missing variance.

\section{$7 \quad$ Appendix A}

\begin{tabular}{|c|c|c|}
\hline Construct & Item & \\
\hline \multirow{3}{*}{$\begin{array}{l}\text { Behavioral } \\
\text { Intention }\end{array}$} & I have intention to perform mobile learning & \multirow{9}{*}[31]{} \\
\hline & I am going to positively utilize mobile learning & \\
\hline & $\begin{array}{l}\text { I have continuing concern about mobile devices of information to perform } \\
\text { mobile learning }\end{array}$ & \\
\hline \multirow{3}{*}{$\begin{array}{l}\text { Performance } \\
\text { Expectancy }\end{array}$} & Mobile learning would improve my learning performance & \\
\hline & Mobile learning can improve efficiency of learning & \\
\hline & Mobile learning gives me high effects of learning & \\
\hline \multirow{3}{*}{$\begin{array}{l}\text { Effort } \\
\text { Expectancy }\end{array}$} & It is easy to download and save learning contents with mobile devices & \\
\hline & It is easy to use menu of mobile devices and software & \\
\hline & It is easy to use mobile learning contents & \\
\hline \multirow{3}{*}{$\begin{array}{l}\text { Social } \\
\text { Influence }\end{array}$} & People who influence my behavior will think that I should use mobile learning & \multirow{3}{*}{ [32] } \\
\hline & $\begin{array}{l}\text { The lecturers and other staff at my college will be helpful in the use of mobile } \\
\text { learning }\end{array}$ & \\
\hline & In general, my college will support the use of mobile learning & \\
\hline \multirow{3}{*}{$\begin{array}{l}\text { Facilitating } \\
\text { Conditions }\end{array}$} & I have the resources necessary to use the system. & \multirow{3}{*}{ [33] } \\
\hline & I have the knowledge necessary to use the system & \\
\hline & A specific person (or group) is available for assistance with system difficulties & \\
\hline \multirow{6}{*}{$\begin{array}{l}\text { Hedonic } \\
\text { Motivation }\end{array}$} & When using mobile learning, I will forget the work I must do. & \multirow{6}{*}{$\begin{array}{l}{[34]} \\
{[35]}\end{array}$} \\
\hline & Using mobile learning will give enjoyment to me for my learning. & \\
\hline & Using mobile learning will lead to my exploration. & \\
\hline & I would find mobile phone very interesting to use & \\
\hline & I would find mobile phone boring to use for learning & \\
\hline & I would find mobile phone exciting to use for learning & \\
\hline \multirow{3}{*}{$\begin{array}{l}\text { Personal } \\
\text { Innovativeness }\end{array}$} & I like to experiment with new information technologies. & \multirow{3}{*}{ [36] } \\
\hline & $\begin{array}{l}\text { When I hear about a new information technology I look forward to examining } \\
\text { it. }\end{array}$ & \\
\hline & $\begin{array}{l}\text { Among my colleagues, I am usually the first to try out a new innovation in } \\
\text { technology. }\end{array}$ & \\
\hline
\end{tabular}




\section{$8 \quad$ References}

[1] Investment, T.B.o., Thailand Moving Ahead with Cluster Development 2017, Thailand Board of Investment. Retrieved from http://www.boi.go.th/upload/con tent/BOI-brochurecluster\%20area-EN-20151116 53354.pdf.

[2] Ghazali N.A., Lafortune E., Latiff M. K. M., Limjaroenrat P, \& Whitesides E. (2011). Thailand Automotive Cluster. Retrieved from https://www.isc.hbs.edu/resources/courses/ moc-course-at-harvard/Documents/pdf/student-projects/Thailand Automotive 2011.pdf.

[3] Senkrua, A. (2015). The Mismatch in Thai labor Market: Overeducation, Journal of Economics Chiang Mai University. 19(1), 92-116. Retrieved from https://www.tcithaijo.org/index.php/CMJE/article/view/61018.

[4] United Nations Educational, Scientific and Cultural Organization (UNESCO). (2003). Analytical survey. The Use of ICTs in Technical and Vocational Education and Training. Moscow: UNESCO. Retrieved from http://iite.unesco.org/pics/publications/en/files/ 3214613.pdf.

[5] Office of the Education Council. (2017). National Education plan 2017-2036. Bangkok: Prikwan. Retrieved from http://backoffice.onec.go.th/uploads/Book/1540-file.pdf

[6] Adewole, E. G. \& Fakorede, S. O. A. (2013). Strengthening the Nigerian higher education system through the use of information communication technology. International Journal of Social Science \& Education, 3(4), 1006-1012.

[7] Keengwe, J. \& Maxfield, M. B. (2015). Advancing higher education with mobile learning technologies: Cases, trends and inquiry-based methods. Hershey, PA: IGI Global. https://doi.org/10.4018/978-1-4666-6284-1

[8] Bhavnani, A., Chiu, R. W., Janakiram, S. \& Silarszky, P. (2008). The Roles of Mobile Phones in Sustainable Rural Poverty Reduction, ICT Policy Division, Global Information and Communications Department (GICT) - The World Bank, Working Paper 44678. Retrieved from http://siteresources.worldbank.org/EXTINFORMATIONANDCOMMU NICATIONANDTECHNOLOGIES/Resources/The Role of Mobile Phones in Sustaina ble Rural Poverty Reduction June 2008.pdf.

[9] Nasiri, A. and Deng, G. (2009). Environmental Factors Influence on Mobile Learning Business. American Journal of Applied Science, 6(6), 1225-1234. https://doi.org/10.3844/ajassp.2009.1225.1234

[10] Liu, T. C., Lin, Y. C., \& Paas, F. (2014). Effects of prior knowledge on learning from different compositions of representations in a mobile learning environment. Computers \& Education, 72, 328-338.

[11] Motlik, S. (2008). Mobile learning in developing nations. The International Review of Research in Open and Distance Learning, 9(2), 1-7. https://doi.org/10.19173/irrodl.v9i2.564

[12] Kalloo, V., \& Mohan, P. (2012). MobileMath: An innovative solution to the problem of poor Mathematics performance in the Caribbean. The Caribbean Teaching Scholar, 2(1), 5-18. Retrieved from https://journals.sta.uwi.edu/ojs/index.php/cts/article/view/27.

[13] Grimus, M., Ebner, M. \& Holzinger, A. (2013). Mobile Learning as a Chance to Enhance Education in Developing Countries - on the Example of Ghana. In: mLearn, Conference on Mobile and Contextual Learning, pp. 340-345.

[14] Göksu, I. \& Atici, B. (2013). Need For Mobile Learning: Technologies and Opportunities. Procedia - Social and Behavioral Science, 103, pp. 685-694. https://doi.org/10.1016/j.sbspro.2013.10.388

[15] Prasertsilp, P. (2013). Mobile Learning: Designing a Socio-Technical Model to Empower Learning in Higher Education. Journal of Transdisciplinary Writing and Research from Claremont Graduate University, 2(1), 1-12. https://doi.org/10.5642/lux.201301.23 
[16] Sha, L., Looi, C.-K., Chen, W., Seow, P. \& Wong, L.-H. (2012). Recognizing and measuring self-regulated learning in a mobile learning environment. Computer in Human Behaviour, 28(2), 718-728. https://doi.org/10.1016/j.chb.2011.11.019

[17] Koole, M. L. (2009). A model for framing mobile learning. Mobile learning: Transforming the delivery of education and training, 1(2), 25-47.

[18] Nordin, N., Embi, M.A. \& Yunus, M. M. (2010). Mobile learning framework for lifelong learning. Procedia - Social and Behavioral Science, 7, pp. 130-138. https://doi.org/10.1016/j.sbspro.2010.10.019

[19] Chambo, F. F., Laizer, L. S., Nkansah-Gyekye, Y. \& Ndume, V. (2013). Mobile Learning Model for Tanzania Secondary Schools: Case Study of Kilimanjaro Region. Journal of Emerging Trends in Computing and Information Sciences, 4(9), pp. 698-701.

[20] Al-Harrasi, H., Al-Khanjari, Z. \& Sarrab, M. (2015). Proposing a new design approach for M-learning applications. International Journal of Software Engineering and its Application, 9(11), 11-24. https://doi.org/10.14257/ijseia.2015.9.11.02

[21] Mohamad, I. \& AlAmeen, A. (2014). Designing An Effective Mobile-learning Model By Integrating Student Culture. International Journal of Computer Science and Security, 8(3), 75-83.

[22] James, P. T. (2008). The $5^{\text {th }}$ Wave: Challenges and Opportunities for Mobile-learning in Thailand. In: Proceedings of the Fifth International Conference on eLearning for Knowledge-Based Society, Bangkok, Thailand. Retrieved from http://www.ijcim.th.org/ SpecialEditions/v16nSP3/07 fullpaper Paul\%20TJ\%20James revised.pdf.

[23] Venkatesh, V., Thong, J., \& Xu, X. (2012). Consumer Acceptance and Use of Information Technology: Extending the Unified Theory of Acceptance and Use of Technology. MIS Quarterly, 36(1), 157-178. Retrieved from http://www.jstor.org/stable/41410412.

[24] Gao, T., Rohm, A., Sultan, F. \& Huang, S. (2012), Antecedents of consumer attitudes toward mobile marketing: a comparative study of youth markets in the United States and China, Thunderbird International Business Review, 54(2), 211-224. https://doi.org/10.1002/tie.21452

[25] Thomas, T. D., Singh, L. \& Gaffar, K. (2013). The utility of the UTAUT model in explaining mobile learning adoption in higher education in Guyana. International Journal of Education and Development using Information and Communication Technology, 9(3), 71-85.

[26] Tan, K. S. \& Tang, J. T. H. (2016). New skills at work: Managing skills challenges in ASEAN-5. Research Collection School Of Economics. Retrieved from http://ink.library.smu.edu.sg/soe research/1891.

[27] Liaw, S. S., Huang, H. \& Chen, G. (2007). Surveying instructor and learner attitudes toward e-learning, Computers \& Education, 49(4), 1066-1080. https://doi.org/10.1016/j.compedu.2006.01.001

[28] Cheng, Y. (2015). Towards an understanding of the factors affecting m-learning acceptance: roles of technological characteristics and compatibility, Asia Pacific Management Review, 20(3), 109-119. https://doi.org/10.1016/j.apmrv.2014.12.011

[29] Jairak, K., Praneetpolgrang, P., \& Mekhabunchakij, K. (2009). An acceptance of mobile learning for higher education students in Thailand. In: Proceeding of the 6th International Conference on E-Learning from Knowledge -Based Society, 17-18 December 2009, Thailand. http://www.ijcim.th.org/SpecialEditions/v17nSP3/v17nSP3.htm

[30] Kim, H. \& Rha, J. (2018). Predicting the Drivers of the Intention to Use Mobile Learning in South Korea. International Journal of Interactive Mobile Technologies, 12(1), 116-132.

[31] Park, S. Y., Nam, M. W. \& Cha S. B. (2012). University student' behavioral intention to use mobile learning: Evaluating the technology acceptance model. British Journal of Education Technology, 43(4), 592-605. https://doi.org/10.1111/j.1467-8535.2011.01229.x 
[32] Mtebe, J. S. \& Raisamo, R. (2014). Investigating student' behavioural intention to adopt and use mobile learning in higher education in East Africa. International Journal of Education and Development using Information and Communication Technology, 10(3), 4-20. Retrieved from https://eric.ed.gov/?id=EJ1059061.

[33] Briz-Ponce, L., Pereira, A., Carvalho, L., Juanes-Mendez, J. A. \& Garcia-Penalvo, F. J. (2016). Learning with mobile technologies - Students' behavior. Computers in Human behavior, 72, 612-620. https://doi.org/10.1016/j.chb.2016.05.027

[34] Karimi, S. (2016). Do Learners' Characteristics matter? An exploration of mobile-learning adoption in self-directed learning. Computers in Human behavior, 63, 769-776. https://doi.org/10.1016/j.chb.2016.06.014

[35] Tajudeen, S. A., Basha, M. K., Michael, F. O. \& Mukthar, A. L. (2013). Determinant of Mobile Devices Acceptance for Learning among Students in Developing Country. The Malaysian Online Journal of Educational Technology, 1(3), 17-29. Retrieved from https://eric.ed.gov/?id=EJ1086388.

[36] Abu-Al-Aish, A. \& Love, S. (2013). Factors Influencing Students' Acceptance of MLearning: An Investigation in Higher Education. The International Review of Research in Open and Distance Learning, 14(5), 82-107. http://doi.org/10.19173/irrodl.v14i5.1631

\section{Authors}

Ekkalak Issaramanoros is a doctoral student at Technopreneurship and Innovation Management program, Graduate School, Chulalongkorn University, Thailand

Jintavee Khlaisang is Associate Professor at the Department of Educational Technology and Communications, Faculty of Education, Chulalongkorn University, Thailand.

Pakawan Pugsee is lecturer at the Department of Mathematics and Computer Science, Faculty of Science, Chulalongkorn University, Thailand.

Article submitted 25 May 2018. Resubmitted 09 June 2018. Final acceptance 08 November 2018. Final version published as submitted by the authors. 